\title{
New Exploration on Bilingual Teaching of Numerical Control
}

\author{
Dongfang $\mathrm{Hu}^{1, \mathrm{a}^{*}}$ and Minlu $\mathrm{He}^{1, \mathrm{~b}}$ \\ ${ }^{1}$ School of Mechatronics Engineering, Henan University of Science and Technology, Luoyang, 471003, \\ China \\ ahdf@haust.edu.cn, bhmljdi@163.com
}

Keywords: Numerical control technology and equipment; Bilingual teaching; Teaching mode; Teaching quality

\begin{abstract}
The current course of numerical control technology and equipment is advocated using bilingual teaching mode. From the training requirements of talents and based on the basic connotation of bilingual teaching, this paper puts forward "the professional English vocabulary as starting point, the English noun concepts of narrative to pave the way, with part sections of English teaching as the goal "of " from point to surface "step-by-step bilingual teaching of CNC. In the paper, the author take the necessity of the bilingual teaching as a breakthrough point, and introduce in three aspects of teachers, students and textbook: how to deal with the current situation of bilingual teaching in the new period, how to establish a reasonable and feasible bilingual teaching mode, how to make rational use of multimedia assisted teaching to add the interest of class, and how to choose an effective bilingual teaching evaluation mechanism. Those all designed to improve the quality of bilingual teaching, achieving the double lifting teaching purpose for professional knowledge and English proficiency. Finally, through the comparative analysis of the experimental teaching and the traditional teaching results, which shows that the reform is effective.
\end{abstract}

\section{Introduction}

As one of the basic courses in mechanical engineering, the course of numerical control equipment technology is necessary adopt the mode of bilingual teaching. Because CNC equipment belongs to a technical course in mechanical engineering and keep pace with the social development, which updates faster. In the "some opinions on strengthening undergraduate education to improve teaching quality " pointed out that undergraduate education should create conditions to use English in public courses and specialized courses teaching, and in the field of information technology and other professional should strive to make foreign language teaching courses achieve the course of 5\% 10\% [1]. While English is international language, bilingual teaching can communicate with advanced technology country conveniently, promote ourselves rapidly. At the same time, using bilingual teaching is the continuation of college English curriculum, which opened in the freshman year and sophomore year in many colleges and universities. Then the students few contact with English, also they don't have the English communication environment. It is extremely unfavorable for individual students in future development. The bilingual teaching in the specialized course of numerical control equipment has just made up for the shortcomings of these aspects. At present, our country numerical control bilingual teaching faces the following problems need to be solved, as is shown in Table 1.

\section{Innovative Bilingual Teaching Mode}

The specialized courses has the dual goals in bilingual teaching, one of which is to enable students to master professional knowledge, and the second is to enhance students' ability of using English[2]. Then ultimate goal can be reached, that is training high qualified talents with professional knowledge and English ability. Based on the consideration of the students' ability to accept English as well as the level of teachers' ability, the paper puts forward a step by step numerical control bilingual teaching mode, which is based on the English vocabulary as the starting point, the English narrative of the noun 
concept as the groundwork, some sections of teaching material in the whole English teaching as the goal.

Table 1 The problems faced by bilingual teaching of numerical control

\begin{tabular}{|c|c|}
\hline Problem & Content \\
\hline $\begin{array}{l}\text { Student's psychological } \\
\text { factors }\end{array}$ & $\begin{array}{l}\text { Students have more or less resistance to the bilingual teaching of } \\
\text { professional courses. Many students think that English is not good, } \\
\text { they have no interest in College English class. }\end{array}$ \\
\hline Lack of faculty & $\begin{array}{l}\text { Lack of the professional teachers who are familiar with the } \\
\text { production practice and can undertake the teaching work, which } \\
\text { restricts the cultivation of practical ability of high skilled talents. }\end{array}$ \\
\hline Teaching model & $\begin{array}{l}\text { In order to achieve the goal of double harvest of professional } \\
\text { knowledge and foreign language ability, the students should be } \\
\text { considered in a comprehensive consideration of the students' ability } \\
\text { to accept the foreign language. }\end{array}$ \\
\hline $\begin{array}{l}\text { Evaluation mechanism of } \\
\text { teaching }\end{array}$ & $\begin{array}{l}\text { Written examination is very important, the students generally } \\
\text { temporary review for it. And they ignore the other learning form. }\end{array}$ \\
\hline $\begin{array}{l}\text { Teaching contents are heavy } \\
\text { theory and less practice }\end{array}$ & $\begin{array}{l}\text { The course is characterized by strong theory, involving a wide range } \\
\text { of fields, which involved in computer control technology, software } \\
\text { technology, mechanical processing technology, etc. At present, the } \\
\text { teaching practice of numerical control technology is less, and the } \\
\text { ability of the students to solve practical problems is less. }\end{array}$ \\
\hline $\begin{array}{l}\text { Teaching content is not } \\
\text { advanced }\end{array}$ & $\begin{array}{l}\text { Mechanical and electrical professional courses in recent years, } \\
\text { although some improvement, but the teaching content is still } \\
\text { relatively old, which can't keep up with the development of new } \\
\text { technology and new technology of modern enterprises }\end{array}$ \\
\hline
\end{tabular}

Take English vocabulary learning as the breakthrough point

Numerical control course is opened in the sixth semester, the CET-4 of class students pass rate is only 50\% 70\% and students have not participated in professional English courses. College students' awareness of the importance of English is obtained through the questionnaire, the survey results are shown in Fig.1. In order to make the students gradually adapt to bilingual teaching, teachers take professional English vocabulary learning as the breakthrough point. The class involved all professional terms at the first time should be explained in English and Chinese contrast. The vocabulary appeared in second time is only expressed in English. The intensive reading and writing of the teacher can help students to master the professional English vocabulary. Also, it is necessary to analysis English vocabulary for teacher, introduction of common root, prefix and suffix, which play a multiplier effect and are beneficial to students on fast memory of English vocabulary.

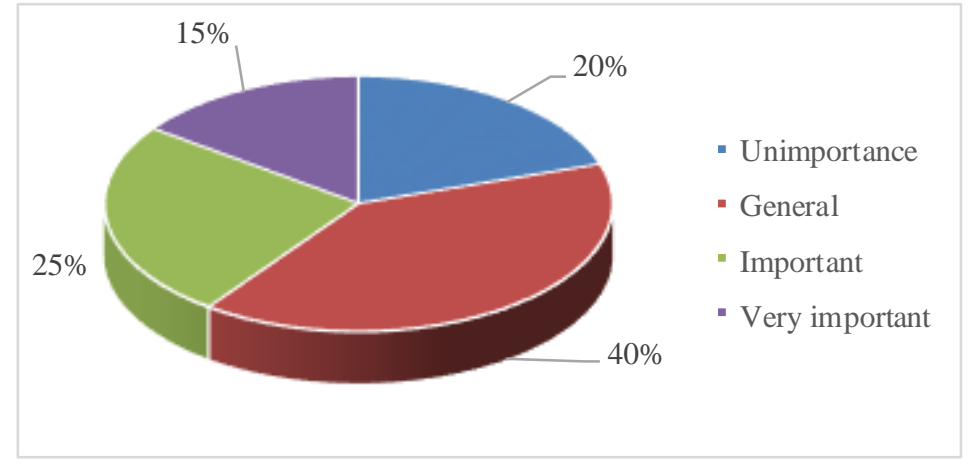

Figure 1. The awareness of English importance of students

The concept terms described in English as transition 
In order to make the students familiar with the terminology and basic concepts of the English expression as soon as possible, teachers should express related terms and concepts all in English, then make students contact with a large number of professional vocabulary. It is difficult for students to accept for English sudden intervention, the beginning of teaching can be added with blackboard or multimedia display and expression in English with Chinese. Then the gradual transition to all English expression is given, the individual difficult concept is given the oral interpretation of Chinese to understand.

A representative section of the whole English class teaching as a demonstration

Most bilingual teaching courses used English version textbook or English courseware. If the bilingual teaching completely in English, the work of teacher' preparation is large and the students are accepted passively. The author suggests that teacher can choose lower difficult selection in fully English teaching during the implementation of the NC bilingual teaching in the curriculum late. In this way, the focus of the teacher can be placed on the narrative of the language rather than the interpretation of knowledge. Therefore, the method can ensure bilingual teaching not affect the students to master the content of professional knowledge. This stage of bilingual teaching purpose is to enable students master the professional knowledge of CNC, guide the students thinking in English style, express their views and reading professional literature. Do well in the above mentioned can enhance students ability in master the English language, cultivate students' self-study ability and innovative ability.

\section{Comprehensive Coordination and Synchronous Reform}

The class is consists of teachers, students and the teaching materials. The following three aspects are talk about the present conditions of bilingual teaching course of numerical control equipment.

1. Teachers: Professional knowledge and high requirements of professional English expression level are needed in bilingual course. If the teacher's professional knowledge is sufficient, while the English expression is not very good, this is not a bilingual class. Similarly, a professional English teacher, whose English expression ease but the NC professional mechanism is not clearly enough, this kind of teaching will let students take the course as an ordinary English classes. All this cannot achieve the goal of bilingual teaching. So it is required teachers with a proficient knowledge of numerical control and professional English expression[3].

2. Students: Most of the students are afraid of English, they don't know what teachers say when the teacher use English as the medium of instruction. Students should overcome their psychological barriers. They should enhance themselves from focusing on the usual accumulation. If something do not understand, the students need to consult teachers in time, which is not only conducive to improve the efficiency of lectures, but also enhance their expression ability.

3. Textbook: The material is combine point of the teacher and the student. For the bilingual curriculum efficiently and orderly, the selection of teaching material is the most important. The bilingual teaching must have corresponding English textbooks, and consideration most students' English level can not good understanding of original materials[4]. It is necessary to choose textbook of properly difficult. At the same time, the colleges should encourage teachers written English textbook, which can appropriate introduce the latest progress in NC field and supplement the hot spot of the current research [5]; During teaching basic knowledge of CNC, the teacher should make up for the new developments in the CNC field. According to the characteristics of students in mechanical engineering, teaching materials should focus on cultivating students' comprehensive quality and innovative ability.

4. Make full use of teaching resources.

The appropriate use of multimedia and auxiliary simulation software in the classroom will greatly enhance the interest of the curriculum. Object teaching can provide a convenient condition for the teaching of numerical control engineering. Teachers need to do a good job of classroom resources integration and grasp the latest developments in the field of CNC in pre-class. Then bilingual teaching should make full use of teaching films, videos, multimedia courseware and so on. To arouse students' 
learning interest, so as to facilitate the students' understanding and memory of classroom teaching contents to realize the effect of bilingual teaching.

\section{Establish Reasonable and Feasible Interactive Bilingual Teaching}

(1) Creating high quality bilingual teaching atmosphere. Most of the explanation of teaching contents is completed in English. Something difficult is used a small number of Chinese to be added. Choose the proper English teaching materials, ask the students to answer the questions in English and finish the homework. In this way, students not only learn the professional technical knowledge, but also improve the level of English application.

(2) Elaborating courseware of bilingual multimedia teaching. Editing equipment, tooling, fixture and process et al. in English to teaching courseware, which only be seen in the laboratory or factory. During the course, the teacher can organize students to watch the video of latest research and application results in field of numerical control technology to explore the vision of the students and stimulate their learning passion.

(3) Interactive teaching. In the classroom, the teacher is no longer just a lecture and no response to the students, but according to the specific circumstances set some "node" in the teaching content. The teacher puts forward some problems and discussion with the students. This teaching method can make students have a strong sense of participation and achievement. The teaching environment can not only real understanding the situation of the students' mastery of the teaching content, but also cultivate students' ability to analyze and solve problems.

(4) Encouraging students to study independently. For the important chapter, some questions should be raised in advance by teachers, which can make the students with the problems to check the information and then get the knowledge of the chapter. The discussion of students not only active classroom atmosphere, but also deepen the understanding of professional knowledge.

(5)Effective supervision and evaluation of teaching. The bilingual courses use the combination of usual test scores and grades scoring. Only in this way can urge the students to work in peacetime. Final assessment results are consist of three parts, that is the assignments in class, class-interaction records, the results of the paper. According to the actual situation, the colleges and universities can be selected flexibly assessment methods, such as written, oral, closed book, open book, semi open book, classroom test, final exam et al [6].

\section{Comparison of Teaching Practice}

The experimental class has carried out the above reform method of numerical control bilingual teaching. In order to clarify whether the direction of reform is effective or not, the traditional mode of bilingual teaching and the innovation teaching mode of teaching results were compared. Comparative data are the results of the assessment of teaching in the past five years, the results as shown in Fig. 2:

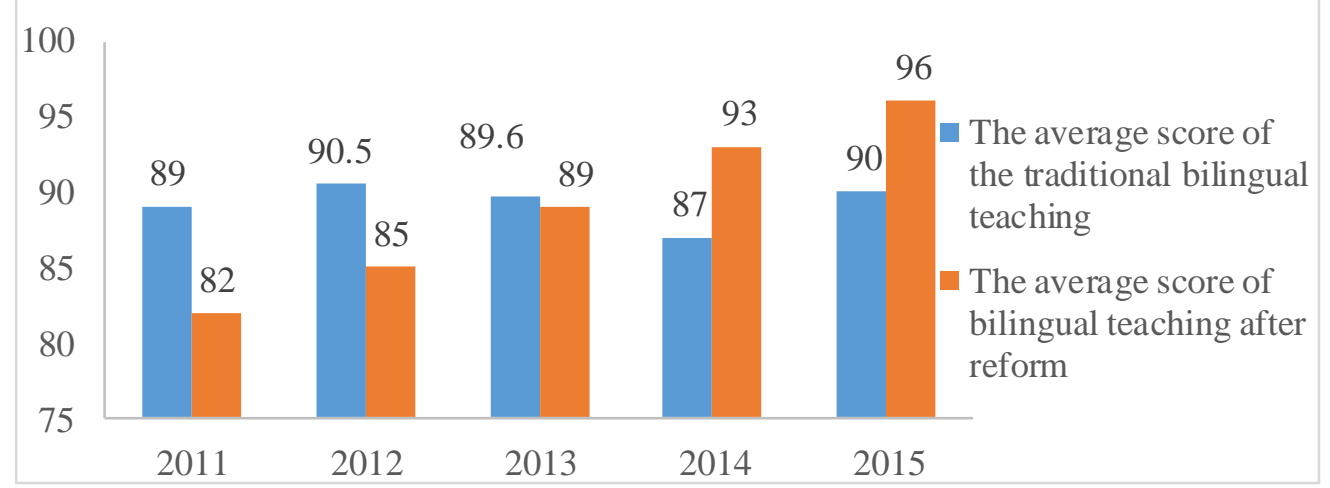

Figure 2. Comparison of teaching achievement 


\section{Conclusion}

Numerical control is a science and engineering course, which is difficult for students to learn the knowledge in Chinese. In addition, most students are not able to use the professional English flexibly, which has added new difficulty to the smooth development of bilingual teaching. In summary, according to their own actual situation, each university should arrange the teaching task and learning plan of the numerical control bilingual course reasonably. What's more, teachers should be clear the objectives of the bilingual teaching in the future, and make a summary of the teaching process. Teachers communicate with students to fully mobilize the enthusiasm of the students and help students to overcome the fear of the English language, which can timely find the lack of detection of teaching. Bilingual learning involves the integration of two different cultures, and the understanding of different cultures can help people to understand the language. The implementation of bilingual teaching is not the pursuit of fashion, but the need of social development. And each college should create the bilingual teaching which has their own characteristics based on their own conditions.

\section{Acknowledgement}

The authors gratefully acknowledge the Project for Education and Teaching Reform of Henan University of Science and Technology (No. 2012N-007) and the National Superior Course and Bilingual Teaching Demonstration Course for financial support of this research work.

\section{References}

[1] Department of higher education of the Ministry of Education. Some opinions on strengthening the teaching quality of undergraduate education (In Chinese).

[2] Q.F. Su: Journal of Tanzhou University, Vol. 28 (2006) No.3, p.87 (In Chinese).

[3] M.Y. Shi: Journal of Jiaxing College, Vol. 14 (2002) No.z1, p.260 (In Chinese).

[4] S. Ye, J. Lin, and A.H. Yao: Education Forum (2015) No.31, p.148 (In Chinese).

[5] Q. Han: China Higher Education, Vol. 19 (2009) No.1, p.37 (In Chinese).

[6] A.H. Jiang: Journal of Nanjing Universities of Aeronautics and Astronautics (social sciences), Vol. 9, (2007) No.1, p.95 (In Chinese). 